\title{
Psoriasis and the new biologic agents: interrupting a T-AP dance
}

\author{
Scott R.A. Walsh, Neil H. Shear
}

\section{Abstract}

PSORIASIS IS AN IMMUNE-MEDIATED SKIN DISEASE in which chronic Tcell stimulation by antigen-presenting cells (APC) occurs in the skin. This interplay between the T-cell and APC has been likened to a "T-AP dance" where specific steps must occur in sequence to result in T-cell activation and the disease phenotype; otherwise Tcell anergy would occur. Several novel engineered proteins designed to block specific steps in immune activation (biologic agents) have demonstrated efficacy in the treatment of psoriasis. These agents include fusion proteins, monoclonal antibodies and recombinant cytokines. These medications act at specific steps during the T-AP dance either to inhibit T-cell activation, costimulation and subsequent proliferation of T-cells, lead to immune deviation or induce specific cytokine blockades. The potential increased selectivity for specific pathways in immune activation, clinical efficacy and relative safety of these new agents offers an alternative for the treatment of moderate to severe psoriasis.

CMAJ 2004;170(13):1933-41

$\mathrm{P}$ soriasis is a chronic T-lymphocyte (T-cell) mediated inflammatory immune skin disease affecting about $2 \%$ of children and adults. ${ }^{1,2}$ Classified among the papulosquamous diseases (scaling papules), psoriasis presents as erythematous, hyperkeratotic, often pruritic, scaling papules and plaques (Fig. 1). Among the 4.5 million Americans afflicted with psoriasis, about $65 \%$ have mild disease (plaques covering less than $2 \%$ of the total body surface), $25 \%$ have moderate disease $(2 \%-10 \%$ of the body area) and $10 \%$ have severe disease (> $10 \%$ of the body area). ${ }^{3}$ Although mild to moderate disease may be limited in area, disability can still be severe if the disease is visible on the face or limits mobility of the hands or feet. Psoriasis can dramatically affect psychosocial functioning with increased self-consciousness, frustration, depression, feelings of helplessness and suicidal thought. ${ }^{2}$ Author John Updike summarized his own battle with psoriasis: "My torture is skin deep ... [W]e lepers live a long time ... healthy in other respects ... we hate to look upon ourselves. [T]he name of the disease ... humiliation." ${ }^{\prime, 5}$

As psoriasis is a chronic relapsing disease, intermittent treatment may span a lifetime. In order to limit treatment toxicities, the most minimally toxic yet practical approach for the level of body coverage is chosen. An approach to the treatment of psoriasis is shown in Fig. 2. Although highly successful in the treatment of mild disease, topical agents such as corticosteroids, tar, anthralin, calcipotriol or tazarotene become cumbersome to apply as lesional surface area increases. Furthermore, potential side effects of these therapies increase with the level of application. Nevertheless, topical treatment remains an adjunct in more severe disease to limit the requirement for more aggressive therapies. Phototherapy is a popular option in the treatment of more widespread disease. However, ultraviolet light is generally only available in larger treatment centres, requires a major time commitment (2-3 times per week for many months) and can be associated with an increased risk of cutaneous neoplasms. ${ }^{6}$ For moderate to severe disease, oral systemic immunosuppressives such as methotrexate and cyclosporine or oral retinoids are generally the mainstays of therapy. However, because of potentially widespread immunosuppression and possible hepatic or renal toxicities, the use of these agents is often limited.

Biologic agents are specifically engineered proteins designed to block particular immunologic activation steps involved in the pathogenesis of psoriasis. They may offer another treatment option for the $10 \%-35 \%$ of people with moderate to severe psoriasis. Although the various toxicities of these agents are not yet completely known, it is hoped that when geared to specific pathways in immune activation, these proteins may result in potentially less widespread immunosuppression. They also may have less hepatic or renal toxicity than presently available oral agents. Although the great expense of these agents (about US\$7000 to \$20 000

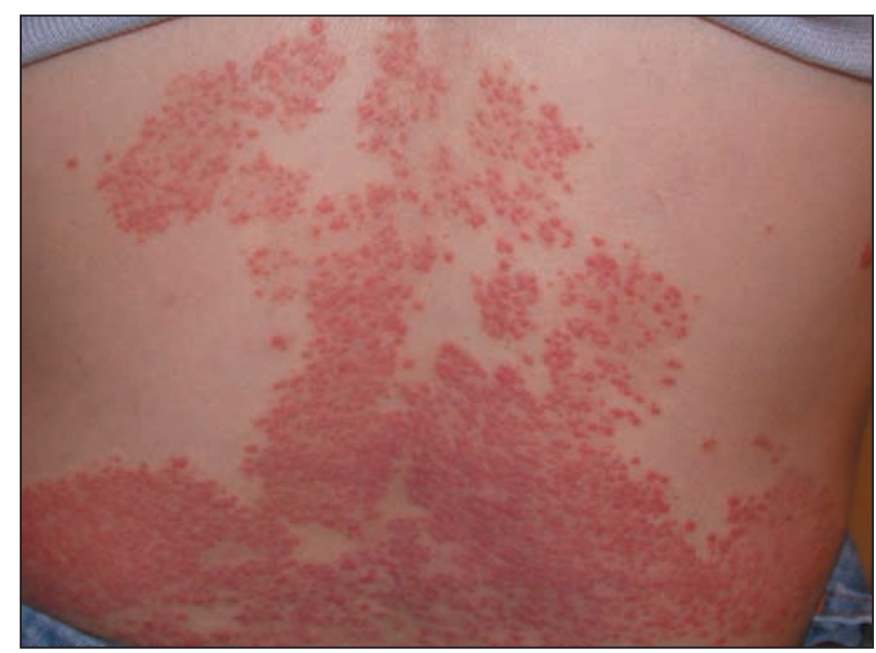

Fig. 1: Widespread psoriasis. Well-demarcated erythematous hyperkeratotic plaque with slight nonconfluent whitish scale. 
per year) may limit their general accessibility, they currently offer another treatment option for patients for whom systemic immunosuppressives or phototherapy have failed, or where these treatments are contraindicated because of comorbid disease. Furthermore, some of these agents appear to have the potential for sustained clinical remissions, not generally seen with our current treatment choices. ${ }^{8}$

\section{Immunobiology of skin}

Proinflammatory cytokines such as tumour necrosis factor-alpha (TNF- $\alpha$ ) or interleukin-1 (IL-1) are not prominent in normal skin but can be produced by activated immune cells or damaged keratinocytes. They signal the need for both a reparative and immunologic response (Fig. 3).

Fig. 4 depicts the initial generation of an immune response to any foreign antigen in the skin. Antigen-presenting cells (APC) mature upon capture of antigen and migrate to the skin-draining lymph node, where they can activate antigen-specific naïve T-cells (see Fig. 5). The mature T-cells proliferate and express the skin-homing marker, cutaneous lymphocyte-associated antigen, which can allow binding to the transmembrane endothelial cell adhesion molecules, Eand P-selectins. When the activated T-cells release cytokines such as TNF- $\alpha$ and interferon-gamma (IFN- $\gamma$ ), regenerative responses can be initiated and other immune effector cells recruited, including neutrophils.

\section{The "T-AP" dance of psoriasis}

Psoriasis is an inflammatory disorder where specific T-cell populations are stimulated by putative antigen presented by APC from the skin. Both helper-type T-cells (CD4) and cytotoxic suppressor-type T-cells (CD8) are involved in psoriasis. ${ }^{1}$ This T-cell/APC ("T-AP") interaction is much like a tap dance where specific steps must occur in sequence to result in T-cell activation; otherwise T-cell anergy would occur. Al- though initial T-AP interactions occur in lymph nodes (Fig. 5), ongoing T-AP interactions appear to subsequently occur in psoriatic plaques in the skin (Fig. 6). ${ }^{1}$ The activated T-cells induce secondary hyperproliferation of epidermal, vascular and occasionally synovial cells through the release of specific cytokine mediators such as TNF- $\alpha$ and IFN- $\gamma .1,9$

Initiation of the T-AP dance occurs when a specific $\mathrm{T}$ cell receptor on a naïve (CD45 RA+) T-cell (CD4 or CD8) encounters its specific processed antigen presented by the APC in the context of major histocompatibility complex proteins (MHC II for exogenous antigens interacting with CD4 T-cells or MHC I for endogenous antigens interacting with CD8 T-cells). Although the nature of the initial stimulating antigen in psoriasis is not known, hypotheses include a molecular mimicry between streptococcal M proteins and human keratins 6 and 17, or the aberrant selfpresentation of cutaneous proteins..$^{10,11}$ Without further APC interaction, this initial interaction would lead to inactivation of the T-cell (i.e., anergy).

In order to prevent T-cell anergy, the APC has costimulatory proteins on its surface that interact with specific $\mathrm{T}$ cell proteins that have been up-regulated through T-cell receptor antigen recognition (Figs. 5 and 7). These molecular interactions activate the T-cells to become memory CD4 or CD8 T-cells (CD45 R0+) and induce expression of CD2, IL-2 and IL-2 receptor (IL-2R or CD25). These latter molecules are necessary for subsequent $\mathrm{T}$-cell proliferation and survival (Fig. 5). T-cells activated in skin-draining lymph nodes also acquire cutaneous lymphocyte-associated antigen, which allows them to interact with $\mathrm{E}$ - and P-selectins on the endothelial surfaces of the cutaneous vasculature, thus targeting them to sites of cutaneous inflammation.

As T-cell activation occurs, 2 distinct lines of differentiation are possible. Under the influence of IL-12 or IFN- $\gamma$, CD4 T-cells differentiate into a TH1 phenotype and CD8 T-cells differentiate into a TC1 phenotype, both with expression of TNF- $\alpha$, IL-2 and IFN- $\gamma$. This response is asso-

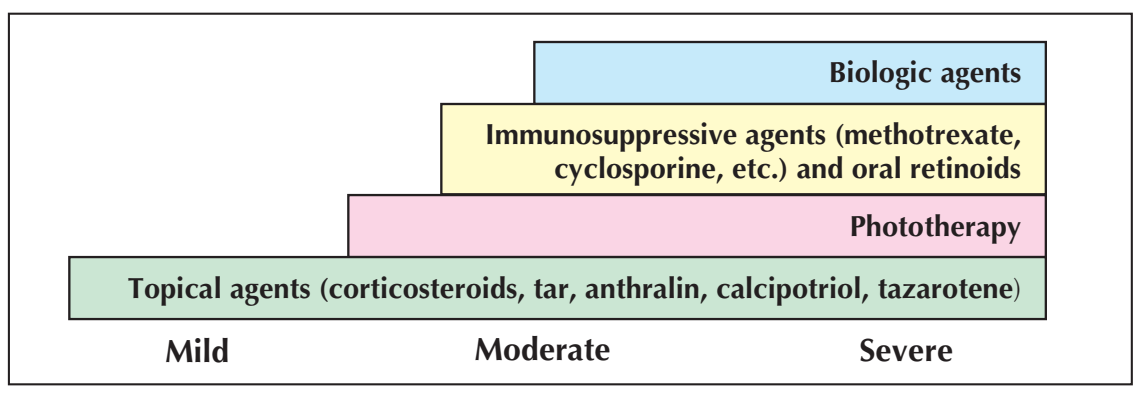

Fig. 2: Approach to the treatment of psoriasis. Topical therapy alone is used to treat mild disease $(<2 \%$ of the total body surface area). It becomes adjunctive therapy in moderate $(2 \%-10 \%$ of the surface area) and severe $(>10 \%$ of the surface area) disease to limit the need for treatments that will be potentially more toxic to the patient. Phototherapy is an option for moderate to severe disease. Immunosuppressive agents and oral retinoids can be considered for widespread moderate and severe disease. The biologic agents represent a newer treatment option for people with this severity of disease. Severe disease also includes body areas that may be limited in extent, but result in functional limitations, such as hand and foot involvement. 
ciated with increased cell-mediated immunity and diseases such as psoriasis. Alternatively, under the influence of IL-4 or IL-10, CD-4 T-cells differentiate into a TH2 phenotype and CD8 T-cells differentiate into a TC2 phenotype, both with expression of IL-4, IL-6, IL-10 and IL-11. This response is associated with antibody production and allergic diseases such as atopic dermatitis (Fig. 5). The favoured differentiation pathway is determined by both the site of T-cell activation and the cytokine profile released by the APC.,12

In psoriasis, activated CD4 memory T-cells localize to the dermis and activated CD8 memory T-cells localize to the epidermis (Fig. 6). Production of inflammatory cytokines by these T-cells induces keratinocytes to express intercellular adhesion molecule 1 (ICAM-1), CD40 and MHC II, enabling further direct interactions between the keratinocyte and T-cells. TNF- $\alpha$ released from T-cells also induces keratinocytes to produce vascular endothelial cell growth factor, resulting in neighbouring endothelial cell proliferation, expression of ICAM and vascular cell adhesion molecules (VCAM) and further recruitment of activated T-cells into the skin through LFA-1. At this point, mature APC no longer need to migrate to the lymph node to present antigen. Instead, the psoriatic plaque begins to act as of a lymph node, with ongoing activation of T-cells by APC in the skin itself. Keratinocytes also produce IL-8 in response to TNF- $\alpha$, which is chemotactic for neutrophils. Movement of neutrophils and CD8 TC1 cells through the epidermis in conjunction with IFN- $\gamma$ produced by activated T-cells and APC results in a regenerative response by the keratinocytes with release of additional proinflammatory cytokines, including IL-1 and IL6. The net result is increased proliferation and aberrant maturation of keratinocytes, manifested by elongation of the rete ridges, loss of the granular layer and parakeratosis (retained nuclei in the stratum corneum) - the hallmarks of psoriasis. ${ }^{1,7,12-14}$

\section{The new biologic agents: interrupting the T-AP dance}

The era of biological therapy began with early studies involving a fusion protein, denileukin diftitox, which is constructed by conjugating diphtheria toxin to soluble IL2. This approach effectively targeted activated T-cells and

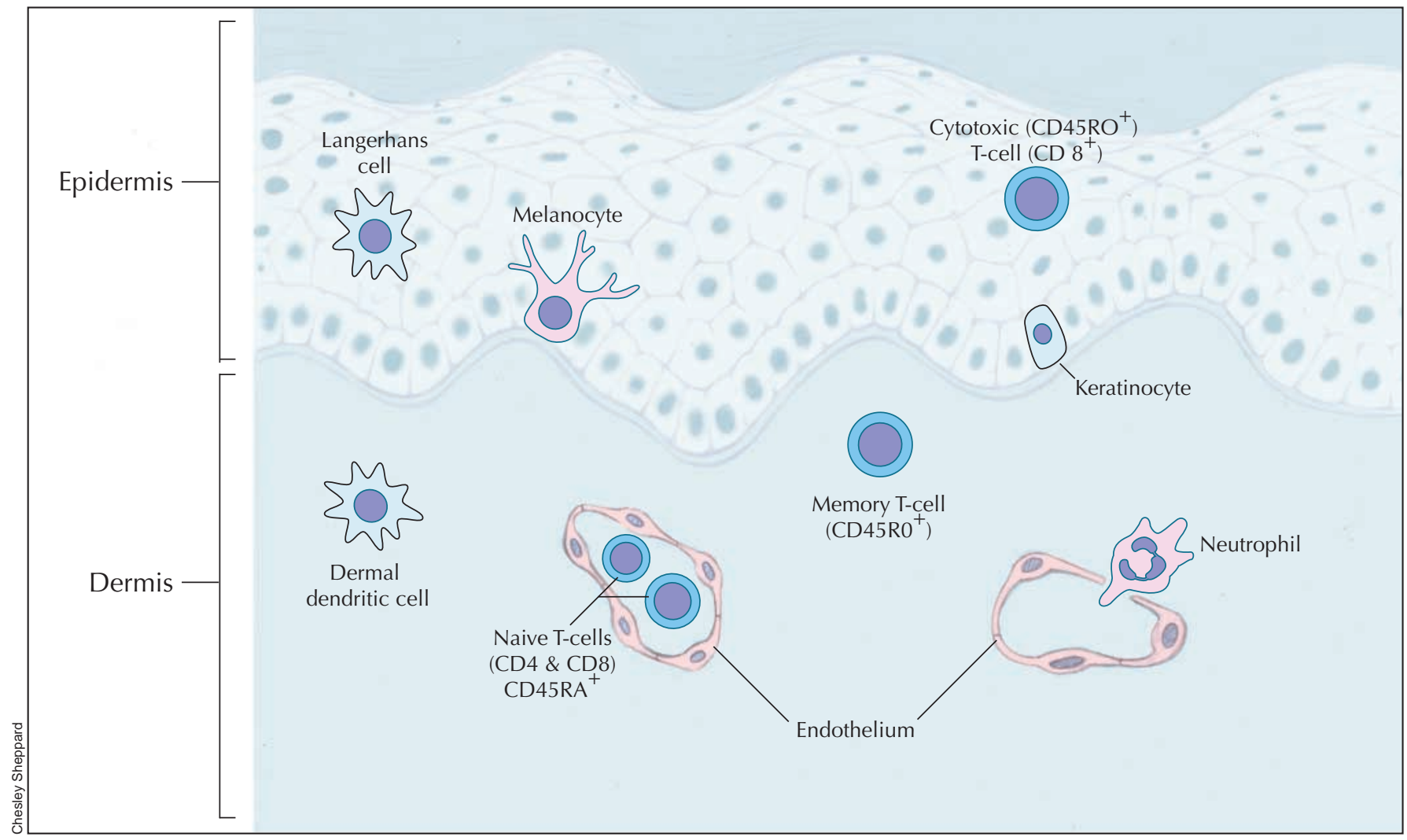

Fig. 3: Cellular players involved in generating immunological reactions in the skin. Langerhans' cells and dermal dendritic cells are specialized antigen-presenting cells (APC) that sample antigen found in the epidermis and dermis, respectively. The majority of the T-cells in normal skin are found in the vasculature and deeper in the lymph nodes (not shown in figure) and represent naïve T-cells (marked by CD45RA+) that have not yet been stimulated to maturity by antigen presentation. Rare T-cells found in the dermis and epidermis likely represent residual memory T-cells present from previous immune activation (these are CD45RO+). Tcells can be helper-type (CD4+) or cytotoxic, suppressor-type (CD8+). Neutrophils and other immune cells can be recruited from the blood vessels into the dermis in response to immune activation cues from endothelial cells, keratinocytes or T-cells. 
improved psoriasis, but side effects of treatment, including vascular leak syndrome, limited its application in cutaneous disease. Nevertheless, targeting the T-cell was demonstrated to improve psoriasis..$^{15,16}$

The new biologic agents are recombinant proteins designed to inhibit specific steps in the T-AP dance by blocking $\mathrm{T}$-cell activation and costimulation and subsequent $\mathrm{T}$ cell proliferation or survival, altering the $\mathrm{TH} 1 / \mathrm{TC} 1$ to a TH2/TC2 pathway (i.e., immune deviation), or blocking cytokine communication (Table 1 and Fig. 7). Nomenclature for these new agents can be fairly confusing, but generally reflects the delivery approach: antibody, fusion protein or cytokine. ${ }^{13,17}$ Monoclonal antibodies can be chimeric with fused mouse and human segments (designated "-ximab"), humanized with intermittent murine sequences (designated "-zumab") or monkey sequences (primatized) in a human backbone, or fully human. Humanized antibodies permit the most flexibility in design, generating minimal blocking of human antimurine antibodies. Fusion proteins are fully human constructs often between the constant $(\mathrm{Fc})$ portion of an immunoglobulin molecule and the binding site of a receptor (designated “-cept"). Finally, recombinant human cytokines can be used as treatment to modify the direction of immune maturation.

\section{T-AP 1: blocking T-cell activation and costimulation}

The sequence of interactions between the T-cell and APC has been the focus for development of the majority of the new biologic agents. Specific agents that interrupt the T-AP dance at this level of T-cell activation and APC cos-

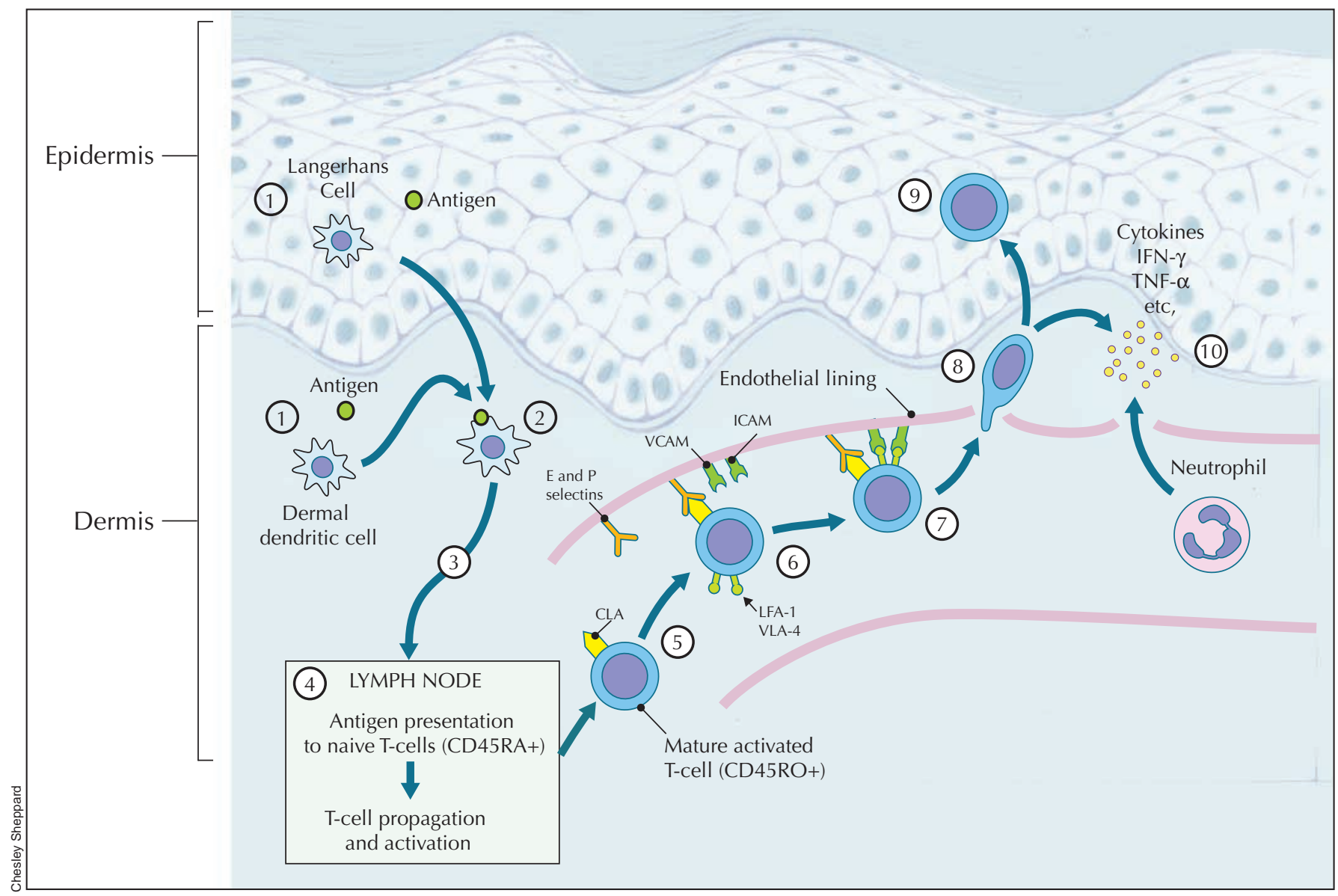

Fig. 4: Initial generation of an immune response in skin. (1) Langerhans' cells and dermal dendritic cells capture antigen. (2) While antigen is processed and presented on the surface of the APC, maturation occurs with the expression of costimulatory molecules. (3) The APC migrate via the afferent lymphatics to the skin-draining lymph node. (4) In the lymph node, they present the processed antigen to naïve T-cells (CD45RA+) (Fig. 5) causing T-cell maturation, activation and proliferation. (5) Mature activated T-cells (CD45RO+) express CLA antigen. (6) CLA antigen is able to bind to E- and P-selectins expressed by endothelial cells in the dermis. (7) This interaction stimulates T-cells to express LFA-1 and VLA-4 and endothelial cells to produce intercellular and vascular adhesion molecules (ICAM and VCAM). (8) The interaction of these molecules allows the activated T-cells to migrate through the postcapillary venules into the dermis. (9) The activated T-cells can then migrate to areas of antigen expression in the dermis or epidermis. (10) The activated T-cell can secrete cytokines such as IFN- $\gamma$ or TNF- $\alpha$ and recruit other immune effector cells, including neutrophils. 
timulation include alefacept, siplizumab, efalizumab, IDEC-114, CTLA4Ig, orthoclone and visilizumab.

Fig. 7 diagrammatically demonstrates how alefacept, siplizumab and efalizumab interrupt the T-AP dance. Alefacept is a fusion protein composed of the APC costimulatory molecule LFA-3 linked to the Fc portion of human $\mathrm{IgG}_{1}$. Binding of alefacept to CD2 previously up-regulated on memory effector T-cells not only blocks necessary signals for costimulation in the T-AP dance, but it also triggers memory $\mathrm{T}$-cell apoptosis through binding of the $\mathrm{Fc}$ portion of the fusion protein to receptors on natural killer cells. ${ }^{8,18}$ This reduction in activated memory T-cells appears to be responsible for the prolonged and sustained clinical remissions of psoriasis obtained with single courses of alefacept treatment. ${ }^{8,18,19}$ Furthermore, the selectivity of this agent for activated memory T-cells via LFA-1/CD2 interaction limits the amount of global immunosuppression. CD2 is also the target for the humanized monoclonal antibody siplizumab. Binding of this antibody to $\mathrm{CD} 2$ on $\mathrm{T}$ cells also prevents costimulation from LFA-3 on APC and may produce prolonged clinical remissions. ${ }^{20}$

Humanized monoclonal antibodies to other costimulatory molecules can also be used to block T-cell activation. Efalizumab, which binds to LFA-1 on T-cells, blocks APC interaction with ICAM-1, -2 and -3 , and also may block Tcell migration into skin through similar receptors expressed

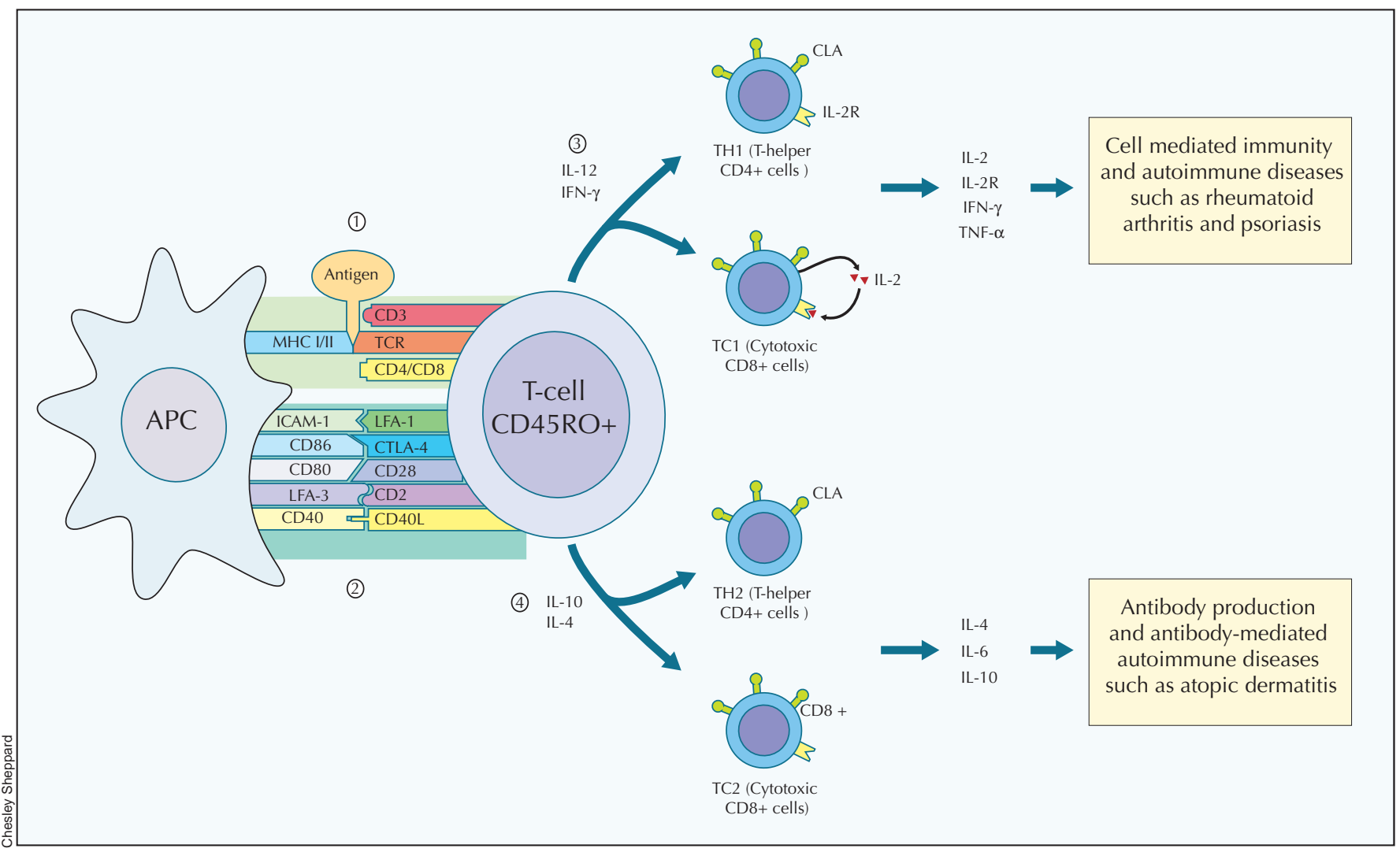

Fig. 5: Stimulation of naïve T-cells by activated APC in the skin-draining lymph node. (1) Naïve T-cells (CD45RA+) can be either CD4+ (T-helper cells) or CD8+ (cytotoxic, suppressor) and recognize antigen presented by APC in the context of major histocompatibility complex (MHC) proteins II or I, respectively. (2) Costimulatory molecules induced on the T-cells by this interaction with APC (the T-AP dance) include LFA-1, CTLA-4, CD28, CD2 and CD40 ligand. These bind to upregulated costimulatory molecules on the APC which include ICAM-1, CD86, CD80, LFA-3 and CD40. Without costimulatory molecular interactions, binding of the T-cell receptor with MHC-presented antigen by the APC would result in T-cell anergy rather than stimulation. (3) In the presence of IFN- $\gamma$ or IL-12 from the APC, T-cells differentiate into a memory (CD45RO+) TH1 (helper CD4+ cells) or TC1 (cytotoxic CD8+ cells) phenotype with expression predominantly of cytokines such as IL-2, IFN- $\gamma$, and TNF- $\alpha$ and the cytokine receptor IL-2R. IL-2 production in conjunction with IL-2R leads to autocrine proliferation of T-cells. This TH1/TC1 response is associated with cellmediated immunity and autoimmune diseases such as psoriasis and rheumatoid arthritis. ${ }^{1}$ (4) In the presence of IL-10 or IL-4, Tcells differentiate into a memory (CD45RO+) TH2 (helper CD4+ cells) or TC2 (cytotoxic CD8+ cells) phenotype with expression of IL-4, IL-6 and IL-10. This TH2/TC2 response is associated with increased antibody production and antibody-mediated autoimmune diseases such as atopic dermatitis. ' Activation and differentiation of T-cells induced by APC from the skin also induces expression of CLA on the surface of the T-cells, which will enable them to return to the skin once maturation is complete. Further interaction between activated T-cells and endothelial cells include LFA-1 and VLA-4 with ICAM and VCAM, respectively. These interactions are important for the localization of the activated T-cells to sites of cutaneous inflammation. 
on endothelial cells and activated keratinocytes. ${ }^{21}$ Although early trials suggested that clinical remissions were generally not sustained, bimonthly maintenance therapy was found to prevent lesion recurrence in the majority of responders. ${ }^{22}$

Several other agents designed to block costimulation were investigated with respect to psoriasis, but such studies were terminated at early phases because of either low efficacy or potentially serious adverse events. Primatized monoclonal antibody IDEC-114 directed against CD-80 on APC blocks costimulation with CD28 on T-cells, resulting in anergy rather than activation. Although preliminary studies suggested that this approach had some effect on psoriasis, ${ }^{7,23}$ the level of clinical efficacy did not support fur- ther phase II testing. Similarly, the fusion protein CTLA4Ig, composed of the binding domain CTLA4 attached to $\operatorname{IgG}_{1}$, blocks the T-AP dance by binding with both CD-80 and CD-86 on APC. Again, preliminary studies suggested some efficacy in psoriasis; however, given the more global abrogation of $\mathrm{T}$-cell responses with this medication, its potential use in psoriasis is severely limited. ${ }^{24,25}$

Methods designed to inhibit T-cell activation by inducing T-cell anergy with CD4- or CD3-specific antibodies have also had very limited applications to psoriasis. Nondepleting anti-CD4 antibodies humanized from either rats (hIgG1-CD4) ${ }^{26}$ or mice (orthoclone) ${ }^{27}$ and the humanized anti-CD3 antibody visilizumab ${ }^{28}$ induce T-cell anergy and

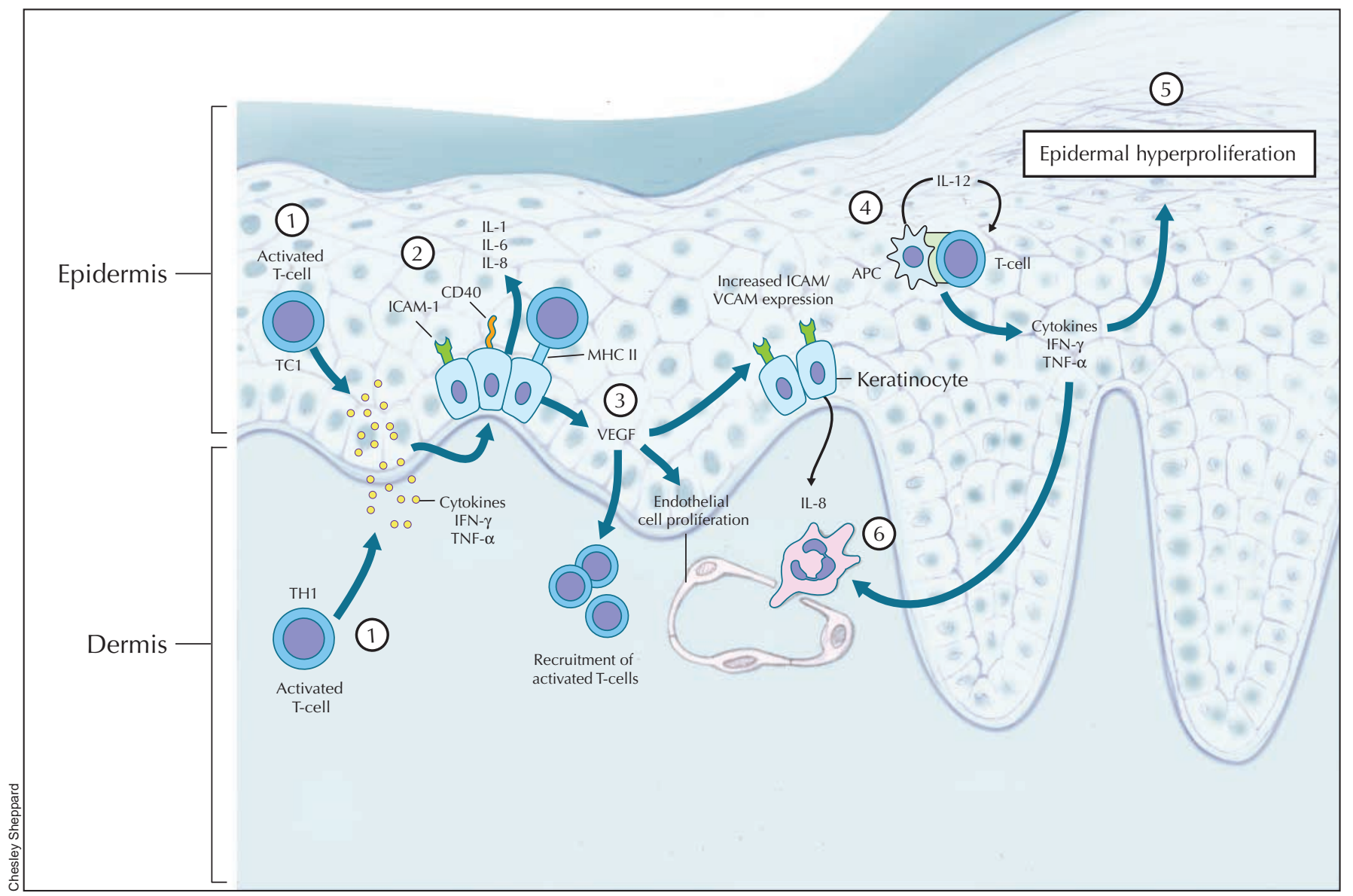

Fig. 6: The immunology of psoriasis. Immune activation occurs as APC process antigen, become activated, migrate to the local skin-draining lymph node and stimulate naïve T-cells to become activated memory T-cells expressing a TC1 or TH1 phenotype, which can then return to the skin via expression of CLA and LFA-1 (Figs. 4 and 5). (1) These activated T-cells express inflammatory cytokines TNF- $\alpha$ and IFN- $\gamma$ which can (2) induce keratinocytes to produce adhesion molecules such as ICAM-1, costimulatory molecules such as CD40 and MHC II molecules for antigen presentation, facilitating further T-cell/keratinocyte interactions. (3) TNF- $\alpha$ also induces keratinocytes to produce vascular endothelial cell growth factor (VEGF) which causes endothelial cell proliferation, increased ICAM/VCAM expression and subsequent increased recruitment of activated T-cells. Keratinocytes also produce other proinflammatory cytokines such as IL-1 and IL-6 that are involved in regenerative responses. (4) Ongoing antigen stimulation between activated APC and T-cells can occur in the epidermis without the need for further APC migration to the lymph node. This is skewed to the TC1/TH1 phenotype by IL-12 produced by the APC. IFN- $\gamma$ and TNF- $\alpha$ that are continually produced result in a regenerative phenotype of the keratinocytes, manifested as (5) epidermal hyperproliferation with elongation of the rete ridges, loss of the granular layer and retained nuclei in the stratum corneum (parakeratosis). (6) TNF- $\alpha$ also induces keratinocytes to produce IL-8 that is chemotactic for neutrophils. 
inhibit $T_{H} 1$ responses by unknown immune mechanisms. These agents have yielded mixed results in early trials and their future application to psoriasis is questionable. ${ }^{26-29}$

\section{T-AP 2: blocking proliferation and survival of activated T-cells}

Once the T-AP dance has started, subsequent T-cell proliferation can be inhibited either by blocking the growth signal required by the T-cells (IL-2 binding to the IL-2 receptor [CD25]) or by directly killing activated T-cells with a toxin-ligated IL-2. Both of these treatments have demonstrated limited efficacy in psoriasis and are undergoing continued investigation. ${ }^{30,31}$

\section{T-AP 3: causing immune deviation}

The third method in blocking the T-AP dance is immune deviation (Table 1, Fig. 7). This approach exploits the competition between $\mathrm{T}_{\mathrm{H}} 1$ and $\mathrm{T}_{\mathrm{H}} 2$ cytokines and their mutual down-regulation. Psoriatic $\mathrm{T}_{\mathrm{H}} 1$ cytokines secreted by APC and activated T-cells (e.g., IFN- $\gamma$, IL-12) can be inhibited and down-regulated by exogenous $\mathrm{T}_{\mathrm{H}} 2$ cytokines (e.g., IL-4, IL-10 and IL-11). This also reduces proinflammatory cytokines such as TNF- $\alpha$. Clinical trials with both IL- ${ }^{32}$ and IL- $11^{33}$ have yielded promising results, although continuous treatments may be necessary in order to achieve sustained improvement in psoriasis. Although early studies with IL-10 (Tenovil) suggested good efficacy, ${ }^{34,35}$ outcome was not considered sufficiently costeffective to justify further development of this agent for treatment of people with psoriasis.

\section{T-AP 4: blocking cytokines}

Finally, the outcome of the T-AP dance, the proinflammatory cytokine mediators, can be blocked with agents such as etanercept, infliximab, Abx-IL8 and HuZAF. The mouse chimeric antibody infliximab tightly binds both soluble and membrane bound forms of TNF- $\alpha .{ }^{36}$ The fusion protein Etanercept is comprised of two TNF- $\alpha$ receptors linked to $\mathrm{IgG}_{1}$ and can bind only soluble TNF- $\alpha$ and TNF- $\beta .{ }^{37}$ Sustained remissions with limited retreatments have been possible in open label trials with both of these agents. ${ }^{38} \mathrm{Al}-$ though inhibiting a late step in the psoriatic pathway, these
Table 1: Biologic agents currently under review for the treatment of psoriasis

\begin{tabular}{|c|c|c|c|c|}
\hline Biologic agent (brand name) & Mechanism of action & $\begin{array}{l}\text { Mode of } \\
\text { delivery }\end{array}$ & Adverse effects & Surveillance \\
\hline \multicolumn{5}{|c|}{ 1. Inhibition of T-cell activation and costimulation } \\
\hline Alefacept (Amevive) & $\begin{array}{l}\text { Fusion protein of LFA-3 tip and } \operatorname{lgG}_{1} \text { binds to CD2 on } \\
\text { memory T-cell blocking costimulation and inducing T-cell } \\
\text { apoptosis by NK cell bridging to } \operatorname{lgG}_{1} \text { component. }\end{array}$ & IM & $\begin{array}{l}\text { Lymphopenia } \\
\text { Flu-like symptoms }\end{array}$ & CD4 counts \\
\hline Siplizumab (Medi-507) & $\begin{array}{l}\text { Humanized antibody to CD2 on T-cell blocking CD2-LFA-3 } \\
\text { costimulation and stimulating antibody-dependent memory } \\
\text { T-cell lysis. }\end{array}$ & SC & $\begin{array}{l}\text { Lymphopenia } \\
\text { Flu-like symptoms }\end{array}$ & CD4 counts \\
\hline Efalizumab (Raptiva) & $\begin{array}{l}\text { Humanized antibody to CD11 a component of LFA-1 on } \\
\text { T-cell which blocks binding to ICAMs on APC, endothelial } \\
\text { cells and activated keratinocytes. }\end{array}$ & SC & $\begin{array}{l}\text { Flu-like symptoms } \\
\text { Thrombocytopenia } \\
\text { Rebound flares }\end{array}$ & Platelets \\
\hline \multicolumn{5}{|c|}{ 2. Inhibition of T-cell proliferation and induction of T-cell destruction } \\
\hline Daclizumab (Zenapax) & $\begin{array}{l}\text { Humanized antibody to Tac ( } \mathrm{p} 55 \text { ) component of high affinity } \\
\text { IL-2 receptor inhibiting IL-2 binding and T-cell proliferation. }\end{array}$ & & Flu-like symptoms & None \\
\hline Basiliximab (Simulect) & $\begin{array}{l}\text { Chimeric antibody to Tac ( } \mathrm{p} 55 \text { ) component of high affinity } \\
\text { IL-2 receptor inhibiting IL-2 binding and T-cell proliferation. }\end{array}$ & $\begin{array}{l}\text { IV } \\
\text { infusion }\end{array}$ & Flu-like symptoms & None \\
\hline \multicolumn{5}{|l|}{ 3. Immune deviation } \\
\hline IL-4 (RhulL-4) & $\begin{array}{l}\text { Recombinant } \mathrm{T}_{\mathrm{H}} 2 \text { cytokine used to skew } \mathrm{T}_{\mathrm{H}} 1 \text { cells to } \mathrm{T}_{\mathrm{H}} 2 \\
\text { phenotype. }\end{array}$ & SC & $\begin{array}{l}\text { Flu-like symptoms } \\
\text { Peripheral edema }\end{array}$ & None \\
\hline IL-11 (Oprelvekin) & $\begin{array}{l}\text { Recombinant } \mathrm{T}_{\mathrm{H}} 2 \text { cytokine used to skew } \mathrm{T}_{\mathrm{H}} 1 \text { cells to } \mathrm{T}_{\mathrm{H}} 2 \\
\text { phenotype. }\end{array}$ & SC & $\begin{array}{l}\text { Flu-like symptoms } \\
\text { Arrhythmias } \\
\text { Peripheral edema }\end{array}$ & $\begin{array}{c}\text { CBC } \\
\text { platelets }\end{array}$ \\
\hline \multicolumn{5}{|l|}{ 4. Cytokine blockade } \\
\hline Etanercept (Enbrel) & $\begin{array}{l}\text { Fusion protein of two TNF- } \alpha \text { receptors linked to } \operatorname{lgG}_{1} \text { capable } \\
\text { of reversibly binding to both TNF- } \alpha \text { and TNF- } \beta \text {. }\end{array}$ & SC & $\begin{array}{l}\text { Tuberculosis } \\
\text { activation } \\
\text { Demyelinating } \\
\text { disorders }\end{array}$ & None \\
\hline Infliximab (Remicade) & $\begin{array}{l}\text { Chimeric antibody to TNF- } \alpha \text { capable of binding both soluble } \\
\text { and membrane-bound forms. }\end{array}$ & $\begin{array}{l}\text { IV } \\
\text { infusion }\end{array}$ & $\begin{array}{l}\text { Tuberculosis } \\
\text { activation } \\
\text { Infusion reactions }\end{array}$ & None \\
\hline
\end{tabular}


anti-TNF- $\alpha$ agents have yielded the highest response rates among all of the biologics thus far investigated. ${ }^{36-38}$

In contrast to TNF- $\alpha$ inhibitors, success with blocking other proinflammatory cytokines has been limited. Studies with a fully humanized antibody to IL-8 (Abx-IL8) showed only modest improvement in preliminary trials, suggesting that there might be significant redundancy in the role of this cytokine in psoriasis pathogenesis. ${ }^{39}$ As a result, this agent is no longer in development for psoriasis. Novel humanized antibodies to other inflammatory cytokines such as IFN- $\gamma$ (HuZAF) are just beginning phase I clinical trials. ${ }^{40}$

\section{Precautions with biologic agents}

Although these new biologic agents appear to act with greater target specificity than the systemic immunosuppressives that are currently available, questions remain regarding their safety in patients with ongoing or latent infection, immunosuppression or malignancy. For example, TNF- $\alpha$ appears to be critical for the maintenance of gran- ulomatous-type responses, and the TNF- $\alpha$ inhibitors infliximab and etanercept have been associated with tuberculosis infection or reactivation. ${ }^{41}$ Since both alefacept and siplizumab result in antibody-mediated cytotoxicity of activated memory T-cells, treatment with these agents can cause a significant drop in T-cell counts. ${ }^{8,20}$ Furthermore, as many of these agents are new on the market, the relevance of potential associated adverse events such as demyelinating diseases has not yet been established. ${ }^{42}$ The safety and efficacy of vaccinations is also uncertain with the immunosuppressive nature of these medications. Overall, the projected high cost poses the greatest potential limitation to the wide availability and accessibility of these agents.

\section{Summary}

The biologic agents represent a refined approach to targeted immunosuppression. At present, it is unclear why not all patients respond to each agent. It is likely that different immune pathways may lead to the psoriatic phenotype and

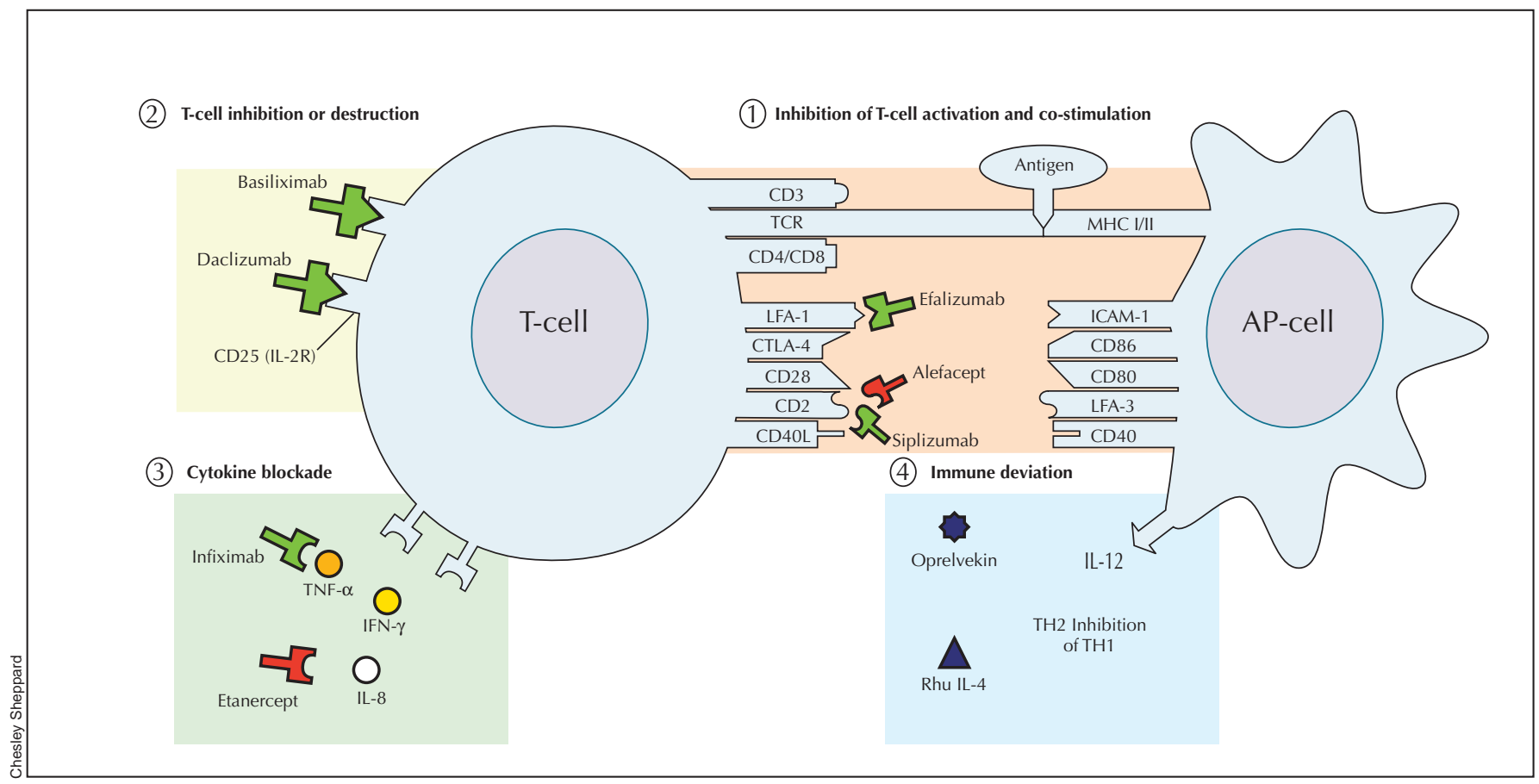

Fig. 7: Biologic agents and their targets - The T-AP dance. Biologic agents either: (1) inhibit T-cell activation and costimulation (efalizumab, alefacept, siplizumab), (2) inhibit T-cell proliferation or induce their destruction (basiliximab, daclizumab), (3) block the effector cytokines (infliximab, etanercept) or (4) cause immune deviation (cytokines IL-11 [Oprelvekin] or IL-4). In the diagram, fusion proteins are red and antibody-based biologic agents are green. Binding of alefacept to CD2 previously up-regulated on memory effector T-cells not only blocks necessary signals for costimulation in the T-AP dance, but it also triggers memory Tcell apoptosis through binding of the Fc portion of the fusion protein to receptors on natural killer cells..$^{8,18}$ Similar to alefacept, siplizumab also interacts with CD2, resulting in reduced memory effector T-cells, and may also produce prolonged clinical remissions. ${ }^{20}$ The chimeric basiliximab ${ }^{30}$ and the humanized daclizumab, ${ }^{31}$ both monoclonal antibodies raised against CD25 on activated T-cells, limit survival of activated T-cells by causing antibody-induced cell lysis. The chimeric anti-TNF- $\alpha$ antibody infliximab tightly binds both soluble and membrane-bound forms of TNF- $\alpha$ and triggers complement-mediated lysis of TNF- $\alpha$-expressing cells. ${ }^{36}$ The fusion protein etanercept is comprised of 2 TNF- $\alpha$ receptors linked to IgG1 and can bind soluble TNF- $\alpha$ and TNF- $\beta .^{37}$ Although this complex is less stable than infliximab-TNF- $\alpha$, both approaches have yielded significant reductions in psoriasis in the majority of patients (Fig. 7, Table 1). ${ }^{36,37}$ 
thus different costimulatory molecules may have different relevance to disease in a specific person. The diversity of biologic agents becoming available to interrupt the T-AP dance of psoriasis, together with their relative safety, may yield additional effective treatment options for moderate to severe psoriasis.

\section{This article has been peer reviewed.}

From the Department of Medicine, Divisions of Dermatology (Walsh, Shear) and Clinical Pharmacology (Shear), Sunnybrook and Women's College Health Sciences Centre, University of Toronto, Toronto, Ont.

Competing interests: Neil Shear has acted as a paid clinical researcher for Serono, Centocor, has received travel assistance to attend advisory board meeting with Biogen Idec and Amgen and is a principal in Ventana Clinical Research Corporation.

Contributors: Neil Shear and Scott Walsh made substantial contributions to conception and design and to the acquisition, analysis and interpretation of data. Scott Walsh drafted the article and Neil Shear revised it critically for important intellectual content. Both authors approved the final version to be published.

\section{References}

1. Krueger JG. The immunologic basis for the treatment of psoriasis with new biologic agents. 7 Am Acad Dermatol 2002;46:1-23.

2. Koo J. Population-based epidemiologic study of psoriasis with emphasis on quality of life assessment. Dermatol Clin 1996;14(3):485-96.

3. Facts - psoriasis. National Psoriasis Foundation; 2002. Available at www.psoriasis .org/facts/psoriasis/ (accessed 2004 Apr 1).

4. Updike J. From the journal of a leper. Northridge, CA: Lord John Press; 1978. p. 21.

5. Ginsburg IH. Coping with psoriasis: a guide for counselling patients. Cutis 1996;57:323-5.

6. Honigsmann H. Phototherapy for psoriasis. Clin Exp Dermatol 2001;26:343-50.

7. Gottlieb AB, Bos JD. Recombinantly engineered human proteins: transforming the treatment of psoriasis. Clin Immunol 2002;105:105-16.

8. Krueger GG, Papp KA, Stough DB, Loven KH, Gulliver WP, Ellis CN. A randomized, double-blind, placebo-controlled phase III study evaluating efficacy and tolerability of 2 courses of alefacept in patients with chronic plaque psoriasis. 7 Am Acad Dermatol 2002;47:821-33.

9. Fearon U, Veale DJ. Pathogenesis of psoriatic arthritis. Clin Exp Dermatol 2001;26:333-7.

10. Prinz JC. Psoriasis vulgaris - a sterile antibacterial skin reaction mediated by cross-reactive T-cells? An immunological view of the pathophysiology of psoriasis. Clin Exp Dermatol 2001;26:326-32.

11. Jablonska S, Majewski S. On the immunopathogenesis of psoriasis. Arch Dermatol 2001;137:229-30.

12. Guenther LC, Ortonne JP. Pathophysiology of psoriasis: science behind therapy. 7 Cutan Med Surg 2002;6:2-7.

13. Mrowietz U. Advances in systemic therapy for psoriasis. Clin Exp Dermatol 2001;26:362-7.

14. Kirby B, Griffiths CEM. Novel immune-based therapies for psoriasis. $\operatorname{Br} 7$ Dermatol 2002;146:546-51.

15. Gottleib SL, Gilleaudeau P, Johnson R, Estes L, Woodworth TG, Gottlieb $\mathrm{AB}$, et al. Response of psoriasis to a lymphocyte-selective toxin (DAB389IL2) suggests a primary immune, but not keratinocyte, pathogenic basis. Nat Med 1995;1:442-7.

16. Martin A, Gutierrez E, Muglia J, McDonald CJ, Guzz C, Gottlieb A, et al. A multicenter dose-escalation trial with denileukin diftitox (ONTAK, DAB389IL-2) in patients with severe psoriasis. 7 Am Acad Dermatol 2001;45: 871-81.

17. Singri P, West DP, Gordon KB. Biologic therapy for psoriasis. Arch Dermatol 2002;183:657-63.

18. Ellis CN, Krueger GG. Treatment of chronic plaque psoriasis by selective targeting of memory effector T lymphocytes. New Engl 7 Med 2001;345:248-55.

19. Lebwohl M, Christophers E, Langley R, Ortonne JP, Roberts J, Griffiths CEM. An international, randomized, double-blind, placebo-controlled phase 3 trial of intramuscular alefacept in patients with chronic plaque psoriasis. Arch Dermatol 2003;139:719-27.

20. Papp K, Langley R, Matheson R, Dingivan C. Safety, tolerance, and biological activity of MEDI-507 (siplizumab) for the treatment of moderate to severe psoriasis [poster]. American Academy of Dermatology meeting. 2002 February 22-27; New Orleans.
21. Gottlieb AB, Papp KA, Lynde CW, Carey W, Powers J, Rist TE, et al. Subcutaneous efalizumab (anti-CD11a) is effective in the treatment of moderate to severe plaque psoriasis: pooled results of 2 phase III clinical trials [poster] American Academy of Dermatology meeting; 2002 Feb 22-27; New Orleans.

22. Gordon KB, Leonardi C, Harvey D, Powers J, Phillips H, Weinstein GD, et al. Continuous treatment improves outcomes in patients with moderate to severe plaque psoriasis treated with subcutaneous (sc) efalizumab (anti-CD11a): results from the phase III trial ACD2058g [poster]. American Academy of Dermatology meeting; 2002 Feb 22-27; New Orleans.

23. Gottlieb AB, Lebwohl M, Totoritis MC, Abdulghani AA, Shuey SR, Romano $\mathrm{P}$, et al. Clinical and histologic response to single-dose treatment of moderate to severe psoriasis with an anti-CD80 monoclonal antibody. 7 Am Acad Dermatol 2002;47:692-700.

24. Abrams JR, Lebwohl MG, Guzzo CA, Jegasothy BV, Goldfarb MT, Goffe $\mathrm{BS}$, et al. CTLA4Ig-mediated blockade of T-cell costimulation in patients with psoriasis vulgaris. 7 Clin Invest 1999;103:1243-52.

25. Sayegh MH. Finally, CTLA4Ig graduates to the clinic. 7 Clin Invest 1999;103 $1223-5$.

26. Isaacs JD, Burrows N, Wing M, Keogan MT, Rebello PR, Watts RA, et al. Humanized anti-CD4 monoclonal antibody therapy of autoimmune and inflammatory disease. Clin Exp Immunol 1997;110:158-66.

27. Gottlieb AB, Lebwohl M, Shirin S, Sherr A, Gilleaudeau P, Singer G, et al. Anti-CD4 monoclonal antibody treatment of moderate to severe psoriasis vulgaris: results of a pilot, multicenter, multiple-dose placebo-controlled study. 7 Am Acad Dermatol 2000;43:595-604.

28. Trajkovic V. Nuvion. Protein Design Labs. Curr Opin Investig Drugs 2002;3: 411-4.

29. Bachelez H, Glageul B, Dubertret L, Fraitag S, Grossman R, Brousse N, et al. Treatment of recalcitrant plaque psoriasis with a humanized non-depleting antibody to CD4. F Autoimmun 1998;11:53-62.

30. Mrowietz U, Zhu K, Christophers E. Treatment of severe psoriasis with antiCD25 monoclonal antibodies. Arch Dermatol 2000;136:675-6.

31. Krueger JG, Walters IB, Miyazawa M, Gilleaudeau P, Hakimi J, Light S, et al. Successful in vivo blockade of CD25 (high-affinity interleukin 2 receptor) on $\mathrm{T}$ cells by administration of humanized anti-Tac antibody to patients with psoriasis. 7 Am Acad Dermatol 2000;43:448-58.

32. Ghoreschi K, Thomas P, Breit S, Dugas M, Mailhammer R, van Eden W, et al. Interleukin- 4 therapy of psoriasis induces Th2 responses and improves human autoimmune disease. Nat Med 2003;1:40-6.

33. Trepicchio WL, Ozawa M, Walters IB, Kikuchi T, Gilleaudeau P, Bliss JL, et al. Interleukin-11 therapy selectively downregulates type I cytokine proinflammatory pathways in psoriasis lesions. 7 Clin Invest 1999;104:1527-37.

34. Asadullah K, Friedrich M, Hanneken S, Rohrbach C, Audring H, Vergopoulos A, et al. Effects of systemic interleukin-10 therapy on psoriatic skin lesions: histologic, immunohistologic, and molecular biology findings. 7 Invest Dermatol 2001;116:721-7.

35. Kimball AB, Kawamura T, Tejura K, Boss C, Hancox AR, Vogel JC, et al. Clinical and immunologic assessment of patients with psoriasis in a randomized, double-blind, placebo-controlled trial using recombinant human interleukin 10. Arch Dermatol 2002;138:1341-6.

36. Chaudhari U, Romano P, Mulcahy LD, Dooley LT, Baker DG, Gottlieb AB. Efficacy and safety of infliximab monotherapy for plaque-type psoriasis: a randomised trial. Lancet 2001;357:1842-7.

37. Mease PJ, Goffe BS, Metz J, Vanderstoep A, Finck B, Burge DJ. Etanercept in the treatment of psoriatic arthritis and psoriasis: a randomised trial. Lancet 2000;356:385-90.

38. Gottlieb AB, Chaudhari U, Mulcahy LD, Li S, Dooley LT, Baker DG. Infliximab monotherapy provides rapid and sustained benefit for plaque-type psoriasis. 7 Am Acad Dermatol 2003;48:829-35.

39. Lhoner ME, Krueger JG, Gottlieb, AB. Clinical trials of a fully human antiIL-8 antibody for the treatment of psoriasis [Abstract]. Br 7 Dermatol 1999;141:989.

40. Krueger JG. Potential new cellular targets of psoriasis. Skin Allergy News 2002;(Suppl);7-9.

41. Gardam MA, Keystone EC, Menzies R, Manners S, Skamene E, Long R, et al. Anti-tumour necrosis factor agents and tuberculosis risk: mechanisms of action and clinical management. Lancet Infect Dis 2003;3:148-55.

42. Mohan N, Edwards ET, Cupps TR, Oliverio PJ, Sandberg G, Crayton H, et al. Demyelination occurring during anti-tumor necrosis factor alpha therapy for inflammatory arthritides. Arthritis Rheum 2001;44:2862-9.

Correspondence to: Dr. Neil Shear, Sunnybrook and Women's College Health Sciences Centre, Division of Dermatology, University of Toronto, 2075 Bayview Ave., Toronto ON M4N 3M5; fax 416 480-6897; neil.shear@sw.ca 